\title{
Role of Terrestrial Bromeliads in Nutrient Cycling, Restinga da Marambaia, Brazil
}

\author{
Rodrigo Camara de Souza ${ }^{1}$, Marcos Gervasio Pereira ${ }^{1}$, \\ Luis Fernando Tavares de Menezes ${ }^{2}$, Telmo Borges Silveira Filho ${ }^{3}$, \\ Avelino Nogueira da Silva ${ }^{4}$
}

\begin{abstract}
${ }^{1}$ Departamento de Solos, Universidade Federal Rural do Rio de Janeiro - UFRRJ, Seropédica/RJ, Brasil ${ }^{2}$ Departamento de Ciências da Saúde, Biológicas e Agrárias, Centro Universitário Norte do Espírito Santo - CEUNES,, Universidade Federal do Espírito Santo - UFES, São Mateus/ES, Brasil

${ }^{3}$ Instituto de Florestas, Universidade Federal Rural do Rio de Janeiro - UFRRJ, Seropédica/RJ, Brasil

${ }^{4}$ Departamento de Polícia Federal Superintendência Regional do Rio de Janeiro, Polícia Federal, Rio de Janeiro/RJ, Brasil
\end{abstract}

\begin{abstract}
This study quantified the aboveground biomass and nutrient contents in terrestrial bromeliads in a dune forest at Restinga da Marambaia, RJ. Data of individuals in "quadrats" $\left(4 \mathrm{~m}^{2}\right)$ marked on a line perpendicular to the sea were collected in August 2001. Diameter (d) and height (h) were the variables that best correlated with the biomass of Quesnelia quesneliana, which presented highest biomass and concentrations of $\mathrm{K}$. The total number of leaves was the variable that best correlated with the biomass of Billbergia amoena and Neoregelia cruenta. N. cruenta presented the highest concentrations of $\mathrm{N}$ and P. Nutrient contents were higher in Q. quesneliana.
\end{abstract}

Keywords: aboveground biomass, Atlantic Rain Forest, sandy coastal plain.

\section{Papel de Bromélias Terrestres na Ciclagem de Nutrientes, Restinga da Marambaia, Brasil}

\section{RESUMO}

Este trabalho quantificou a biomassa aérea e o conteúdo de nutrientes de bromélias terrestres na floresta de duna na Restinga da Marambaia, RJ. Dados de indivíduos em "quadrats" $\left(4 \mathrm{~m}^{2}\right)$ demarcados numa linha perpendicular ao mar foram coletados em agosto de 2001. Diâmetro (d) e altura (h) foram as variáveis que melhor se correlacionaram com a biomassa aérea de Quesnelia quesneliana, que apresentou a maior biomassa e concentrações de K. Número total de folhas foi a variável que melhor se correlacionou com a biomassa em Billbergia amoena e Neoregelia cruenta. N. cruenta apresentou as maiores concentrações de N e P. O conteúdo de nutrientes foi maior em Q. quesneliana.

Palavras-chave: biomassa aérea, Mata Atlântica, planície arenosa costeira. 


\section{INTRODUCTION}

The essential elements pass cyclically through different ecosystem compartments such as soil and plants biomass. This compartiment, due to the large net primary productivity in tropical forests, store the most part of nutrients (Golley et al., 1978), which means standing alive aboveground biomass of trees and shrubs, belowground biomass is composed of root and dead aboveground biomass, which is in turn composed by litter and fallen trunks (Araújo et al., 1999). Estimates regarding this reservoir contribute to the knowledge of the tropical forest ecosystems functioning (Delitti, 1995).

The aboveground biomass may be estimated indirectly by means of regression equations that correlate different allometric variables, such as height and diameter, which are easily measured, with the biomass of plant samples (Araújo et al., 1999). In the Atlantic Forest, this method was employed in the State of Rio de Janeiro for the bromeliad Aechmea nudicaulis (L.) Griseb and palm Allagoptera arenaria (Gomes) O. Kuntze in Restinga de Cabiúnas (Hay et al., 1982) and again for Allagoptera arenaria in Restinga da Marambaia (Menezes \& Araujo, 2000); in the State of São Paulo, for a temporarily flooded Restinga Forest, Lowland, Submontane and Montane Rain Forest (Alves et al., 2010).

In the Atlantic Forest biome, the direct method for estimating biomass was employed in the State of São Paulo at Semidecidual Riparian Forest (Moreira-Burger \& Delitti, 1999), Rain Forest (Burger \& Delitti, 2008) and Restinga Forest (Moreira-Burger \& Delitti, 2010); in the State of Rio de Janeiro for Clusia hilariana Schltdl. at Restinga de Jurubatiba National Park (Dias et al., 2006) and in the State of Paraná at Submontane, Lowland and Foodplain Forests (Tiepolo et al., 2002). Despite the relatively small size of the sampling area and the possibility to extrapolate the average results found to a larger area and similar ecosystems, this method demands the destruction of large amounts of plants and therefore is onerous, quite laborious and has legal restrictions due to cutting the vegetation (Araújo et al., 1999; Moreira-Burger \& Delitti, 2010).

Canopy trees are the most important components for biomass estimates in tropical forest ecosystems, since they receive the highest levels of solar radiation and therefore reflect in large biomass increment (Moreira-Burger \&
Delitti, 1999). However, these same authors verified that other forms of plant may be also important when it comes to plant communities characterized by an open canopy and a dense plant layer colonizing the forest floor. This is the case of the Atlantic Forest, where epiphytes, lianas, bamboo, palms and tree ferns have a relevant biomass contribution (Vieira et al., 2008). In several plant communities at sandy coastal plains, named as Restingas, the biomass estimation may be focused in terrestrial bromeliads, which are important components that form a dense herbaceous layer almost impenetrable in these ecosystems (Henriques et al., 1986; Araujo et al., 1998).

Rosette-forming bromeliad species have a distinct 'tank' for water storage and nutrient acquisition from atmosphere (González et al., 2011), thus these plants contribute to the increasing diversity of habitats, as seen at Restinga da Marambaia (Cogliatti-Carvalho et al., 2001). These plants also improve the soil fertility by litter (Pereira et al., 2005), which has relatively high concentrations of nutrients (Hsu et al., 2002; Oliveira, 2004). Thus, bromeliads may be considered keystone species in ecosystems.

Bromeliads are typically epiphytes in Atlantic Rain Forest, whereas they are usually terrestrial in Restingas (Scarano, 2009). At this later ecosystem, the ecological importance of bromeliads is still higher, due to the restriction of water (Freitas et al., 2000; van Sluys et al., 2004) and the sandy soil generally poor in nutrients (Hay \& Lacerda, 1984; Moraes et al., 1999; Assis et al., 2011). Therefore, bromeliads act as nurse plants facilitating the regeneration of other plant species (Correia et al., 2010) and also may contribute to the survival of several species of amphibians (Teixeira et al., 2002), lizards (Carvalho \& Araujo, 2007) and invertebrates (Favretto et al., 2011).

In general, there are few studies focused in nutrient cycling at Restingas (Moraes et al., 1999; Pires et al., 2006; Paula et al., 2009; Pereira et al., 2012) and until this moment there are no data on the contribution of terrestrial bromeliads for biomass and nutrients stock at these ecosystems. Therefore, such studies contribute to the understanding of nutrient dynamics and energy flow in these ecosystems, in terms of developing measures for their conservation. This study aimed to estimate the aboveground biomass and nutrient contents of terrestrial bromeliads in the dune forest at Restinga da Marambaia, RJ. 


\section{MATERIAL AND METHODS}

\subsection{Study area}

Restinga da Marambaia is partly distributed in the municipalities of Rio de Janeiro, Itaguaí and Mangaratiba, State of Rio de Janeiro, with approximately $49.40 \mathrm{~km}^{2}$ (Roncarati \& Menezes, 2005). The region macroclimate is classified as Aw - Tropical rainy (Köppen, 1948). The average annual air temperature is $23.7^{\circ} \mathrm{C}$, with February and August presenting the highest and lowest average temperatures of the year, $26.8{ }^{\circ} \mathrm{C}$ and $20.9{ }^{\circ} \mathrm{C}$ respectively (Mattos, 2005). The average annual rainfall is $1239.7 \mathrm{~mm}$, mostly (37\%) concentrated from November to March (rainy season) and the minority (15\%) between July and August (dry season) (Mattos, 2005).

This study was conducted in the dune forest, which is located at the east end of Marambaia, under the coordinates $23^{\circ} 03^{\prime} \mathrm{S} ; 43^{\circ} 36^{\prime} \mathrm{W}$, approximately $800 \mathrm{~m}$ and $300 \mathrm{~m}$ distant from the ocean and Sepetiba Bay, respectively. This forest has approximately 527 ha and occurs on top of one single dune with approximately $30 \mathrm{~m}$ height. The soil is classified as Quartzipsamment (Menezes et al., 2005). Although the area is under great water saturation influence, there are no wetlands and the forest floor has an organic material layer of approximately $15 \mathrm{~cm}$ thickness (Menezes \& Araujo, 2000).

The forest canopy has an average height of $8 \mathrm{~m}$ on the slope facing the ocean, and average height of $15 \mathrm{~m}$ on the slope facing the Bay of Sepetiba. In this forest were identified 53 tree species, distributed in 42 genera from 25 families. The forest canopy allows the passage of enough sunlight to form a dense herbaceous layer on the forest floor dominated by bromeliads, with a predominance of Billbergia amoena (Lodd.) Lindl., Neoregelia cruenta (Graham) LB Sm and Quesnelia quesneliana (Brongn.) LB Sm (LFT Menezes, unpublished data). Epiphytes are underrepresented in the area (Menezes \& Araujo, 2005).

\subsection{Aboveground biomass}

The present study considered 30 individuals of each Neoregelia cruenta, Billbergia amoena and Quesnelia quesneliana bromeliad species that protruded from 10 "quadrats" $\left(4 \mathrm{~m}^{2}\right)$ marked on a line perpendicular to the sea, extended side by side across the dune. The allometric variables evaluated were: height $(\mathrm{H}, \mathrm{cm})$, considered as the distance between the highest point of the plant and the soil surface; rosettes diameter (D, $\mathrm{cm}$ ); number of green leaves (GL), dead leaves (DL) and total number of leaves (TL, LL + DL). Then, the total aboveground structures of these plants (leaves, inflorescences and infructescences) was collected, cleaned, stored in paper bags for drying in an oven $\left(80^{\circ} \mathrm{C}, 72 \mathrm{~h}\right)$ and weighed to obtain dry weight (DW). Data collection was conducted in August 2001.

Aboveground biomass $\left(\mathrm{AB}, \mathrm{kg} \mathrm{ha}^{-1}\right)$ of each individual was correlated with the independent variables $(\mathrm{H}, \mathrm{D}$, GL, DL, TL). Among these, we identified the variable that best correlated with the aboveground biomass, based on the highest adjusted regression coefficient $\left(r^{2}\right)$. We used the simple regression model $(y=a x \pm b)$, where $y=$ aboveground biomass of the individual; $\mathrm{x}=$ variable tested $(\mathrm{H}, \mathrm{D}, \mathrm{GL}, \mathrm{DL}, \mathrm{TL}) ; \mathrm{a}$ and $\mathrm{b}=$ regression coefficients. Regression equations and aboveground biomass of each bromeliad species were validated by means of two perpendicular transects $(160 \mathrm{~m} \times 2 \mathrm{~m}$, each one) to the sea, $50 \mathrm{~m}$ distant from each other, extended side by side across the dune.

\subsection{Nutrient concentrations and contents}

Nutrient concentrations and contents were determined in three individuals of each species. The aboveground biomass was ground in an electric Willey mill and subjected to sulfuric acid digestion

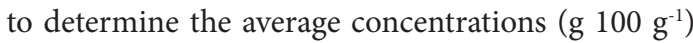
of N, P and $\mathrm{K}$ in the obtained extract (Tedesco et al., 1995). The average content $\left(\mathrm{kg} \mathrm{ha}^{-1}\right)$ of nutrients was calculated by multiplying the average concentration of the respective nutrient by the total aboveground biomass of each bromeliad species.

\section{RESULTS AND DISCUSSION}

\subsection{Aboveground biomass}

In the forest dune of Restinga da Marambaia we sampled 121, 158 and 171 individuals of Quesnelia quesneliana, Neoregelia cruenta and Billbergia amoena, respectively, a total of 450 individuals. The average values of all allometric variables varied widely among the species of bromeliads (Table 1). 
Table 1. Mean allometric values, dry weight and total aboveground biomass of the studied bromeliads species in dune forest at Restinga da Marambaia, Rio de Janeiro, Brazil.

Tabela 1. Valores médios das variáveis alométricas, massa seca e biomassa aérea total das espécies de bromélia estudadas em floresta sobre duna na Restinga da Marambaia, Rio de Janeiro, Brasil.

\begin{tabular}{|c|c|c|c|c|c|c|c|}
\hline \multirow{2}{*}{ Species } & $\mathbf{H}$ & D & GL & DL & TL & \multirow{2}{*}{$\begin{array}{c}\text { DW } \\
---g---\end{array}$} & \multirow{2}{*}{$\frac{\mathrm{AB}}{--\mathrm{kg} \mathrm{ha}^{-1}-}$} \\
\hline & \multicolumn{2}{|c|}{--------cm-------- } & \multicolumn{3}{|c|}{---------unit-------- } & & \\
\hline Billbergia amoena & 52.5 & 58.0 & 14 & 5 & 18 & 22.61 & 28.66 \\
\hline Neoregelia cruenta & 69.0 & 126.5 & 19 & 5 & 23 & 133.00 & 210.40 \\
\hline Quesnelia quesneliana & 71.0 & 83.5 & 32 & 12 & 45 & 40.07 & 352.03 \\
\hline
\end{tabular}

H: heigth; D: diameter; GL: number of green leaves; DL: number of dead leaves; TL: total number of leaves; DW: dry weight; $\mathrm{AB}$ : aboveground biomass.

The average height of Neoregelia cruenta and Quesnelia quesneliana was practically the same, which was 1.3 times higher than that observed for Billbergia amoena. Neoregelia cruenta presented an average diameter 1.5 and 2.2 times higher than Quesnelia quesneliana and Billbergia amoena, respectively. A similar pattern occurred for dry mass, which was 3.3 and 5.9 times higher in Neoregelia cruenta than in Quesnelia quesneliana and Billbergia amoena, respectively (Table 1).

Moreover, in Quesnelia quesneliana the average number of green and dead leaves was approximately twice than the verified to the other species, which reflected a higher total number of leaves in Quesnelia quesneliana. Practically all of the aboveground biomass of bromeliads consisted of leaves. Consequently, Quesnelia quesneliana presented the highest total aboveground biomass, which was 1.7 and 12.3 times higher than that observed for Neoregelia cruenta and Billbergia amoena, respectively (Table 1). In the latter we observed the lowest value of aboveground biomass as a function of the lowest average values for all allometric variables, when compared with other species. The values of total aboveground biomass of each terrestrial bromeliads species in the dune forest at Restinga da Marambaia were lower than that observed for the terrestrial bromeliad Neoglaziovia variegata (Arr Cam) Mez., which value (1.413 $\mathrm{kg} \mathrm{ha}^{-1}$ ) was 2.7 times higher than for the rest of the community of herbaceous plants found in an area of dense and preserved Caatinga in the State of Pernambuco (Albuquerque \& Bandeira, 1995).

Total number of leaves, which ranged from 8 to 27 , was the variable that best correlated with the aboveground biomass of Billbergia amoena $\left(\mathrm{r}^{2}=0.81^{\star}\right)$ in terms of the linear equation $\mathrm{y}=1.2858 \mathrm{x}-1.1614(\mathrm{y}=$ aboveground biomass; $\mathrm{x}=$ total number of leaves). This same pattern was observed for Neoregelia cruenta: total number of leaves, which ranged from 12 to 34 , was also the variable that best correlated with biomass $\left(r^{2}=0.88^{*}\right)$, and the linear equation was $\mathrm{y}=8.6947 \mathrm{x}-79.364$ ( $y=$ aboveground biomass; $\mathrm{x}=$ total number of leaves). Regarding Quesnelia quesneliana, diameter (d), which ranged from 24 to $143 \mathrm{~cm}$, and height (h), which ranged from 27 to $115 \mathrm{~cm}$, were those variables that best correlated with biomass $\left(r^{2}=0.81^{\star}\right)$, expressed by the equation $y=0.0002 x+23.153(y=$ aboveground biomass; $\mathrm{x}=\mathrm{d}^{2} \mathrm{xh}$ ) (Table 1$)$.

Depending on the ecosystem and the aims of the study, different allometric variables may be employed as predictors of plant biomass: canopy diameter, basal diameter, or diameter at breast height (DBH); trunk basal perimeter; height; and wood density (Moreira-Burger \& Delitti, 1999; Vieira et al., 2008). However, there may be differences among them regarding to the correlation with the biomass. The height presented the best correlation with the biomass of Aechmea nudicaulis (L.) Griseb at Restinga de Cabiúnas, in the State of Rio de Janeiro, probably due to the architecture of this bromeliad, overlapping leaves that remind the shape of a "tulip", causing a higher increase in height than in diameter of the plant (Hay et al., 1982). The authors of the former work verified that for Allagoptera arenaria (Gomes) O. Kuntze the diameter of the crown was the variable that best correlated with the biomass of this palm.

The crown diameter was the variable used in mathematical models to estimate the biomass of Allagoptera arenaria at Restinga da Marambaia, which value increased within the distance from the sea (Menezes \& Araujo, 2000). In a Low Restinga Forest, DBH was the variable that generated the most appropriate mathematical model for estimating the biomass of 29 of the 30 tree species studied, while the height was the most suitable variable for estimates the biomass of Syagrus romanzoffiana, a palm species 
that occurred with dense patches and presented high importance value in the area, in the State of São Paulo (Moreira-Burger \& Delitti, 2010).

The total aboveground biomass in a Semidecidual Floodplain Forest, in the State of São Paulo (Moreira-Burger \& Delitti, 1999) was best estimated by the equation generated by the trunk basal perimeter. The estimated total aboveground biomass was based only on DHB in Riparian, Lowland and Submontane Tropical Forests in the State of Paraná (Tiepolo et al., 2002), and in Restinga, Lowland, Submontane e Montane Tropical Forests in the State of São Paulo (Alves et al., 2010). In Tropical Rain Forest in the State of São Paulo, the equation that considered only the height was the least adequate among prediction models obtained to estimate the aboveground biomass, in comparison with the models that considered the product between the square of the diameter and the height or only the diameter (Burger \& Delitti, 2008). According to the former work authors, when the model requires only the diameter to estimate biomass is an advantage because this variable is easily measured and less subjected to sampling errors.

Some studies indicated that the aboveground biomass varies according to the forest type in the Atlantic Rain Forest. In this case, it was observed that a Submontane Rain Forest exhibited higher biomass due to the advanced stage of succession, in comparison with to Lowland Forests and these to Floodplain Forests (Tiepolo et al., 2002). Moreover, Restinga forests, such as those temporarily flooded, have lower biomass than Lowland, Submontane and Montane Forests due to the combination of several factors: more sandy and lower soil fertility, and increased anthropogenic disturbance in Restingas, when compared to the other forests (Alves et al., 2010).

\subsection{Nutrient concentrations and contents}

The concentration of nutrients in the aboveground biomass of Neoregelia cruenta and Quesnelia quesneliana followed the descending order: $\mathrm{K}>\mathrm{N}>\mathrm{P}$ (Table 2). Probably $\mathrm{K}$ was the nutrient with the highest concentration in the biomass of these bromeliads due to high input of marine spray, which favors the accumulation of $\mathrm{K}$ in leaves of plants growing in Restinga (Hay \& Lacerda, 1984).

These results corroborated with those obtained for the aboveground biomass of epiphytes in a tropical forest in Costa Rica (Nadkarni, 1984). This same sequence occurred in litter of epiphytic bromeliads in a well-preserved fragment of Tropical Rain Forest in the State of Rio de Janeiro (Oliveira, 2004). On the other hand, the sequence of nutrient concentrations in Billbergia amoena was slightly different: $\mathrm{N}>\mathrm{K}>\mathrm{P}$ (Table 2). This same pattern occurred for vascular epiphytes in Tropical Moist Forest in Taiwan (Hsu et al., 2002) and in a Tropical Forest in Colombia (Hofstede et al., 1993). However, in a Tropical Forest in Costa Rica this order in litter of vascular epiphytes was: $\mathrm{N}>\mathrm{P}>\mathrm{K}$ (Nadkarni \& Matelson, 1992).

There was variation among bromeliad species in terms of nutrient concentrations. Billbergia amoena and Neoregelia cruenta had the same average concentration of $\mathrm{N}$, which was 1.5 times higher than in Quesnelia quesneliana. The average concentration of P in Neoregelia cruenta was 1.2 and 1.5 times higher than in Billbergia amoena and Quesnelia quesneliana, respectively. However, in these latter species the average concentration of $\mathrm{K}$ was 1.9 and 7.9 times greater than in Neoregelia cruenta and Billbergia amoena, respectively (Table 2).

Table 2. Mean values ${ }^{1}$ of nutrient concentrations and contents in aboveground biomass of the bromeliad species studied in dune forest at Restinga da Marambaia, Rio de Janeiro, Brazil.

Tabela 2. Valores médios ${ }^{1}$ de concentração e conteúdo de $\mathrm{N}, \mathrm{P}$ e $\mathrm{K}$ na biomassa aérea das espécies de bromélia estudadas em floresta sobre duna na restinga da Marambaia, Rio de Janeiro, Brasil.

\begin{tabular}{|c|c|c|c|c|c|c|}
\hline \multirow{3}{*}{ Species } & \multicolumn{3}{|c|}{ Concentration } & \multicolumn{3}{|c|}{ Content } \\
\hline & $\mathbf{N}$ & $\mathbf{P}$ & $\mathbf{K}$ & $\mathbf{N}$ & $\mathbf{P}$ & $\mathbf{K}$ \\
\hline & \multicolumn{3}{|c|}{--------g 100g-1-------- } & \multicolumn{3}{|c|}{-------kg ha'-------- } \\
\hline Billbergia amoena & 0.187 & 0.050 & 0.067 & 0.008 & 0.002 & 0.002 \\
\hline Neoregelia cruenta & 0.187 & 0.060 & 0.274 & 0.059 & 0.019 & 0.086 \\
\hline Quesnelia quesneliana & 0.128 & 0.040 & 0.530 & 0.067 & 0.021 & 0.279 \\
\hline
\end{tabular}

${ }^{1}$ Values obtained from the average of three replicates. 
The average $\mathrm{N}$ content was approximately 1.1 and 8.4 times higher in Quesnelia quesneliana than Neoregelia cruenta and Billbergia amoena, respectively. The same occurred for P, which was 1.1 and 10.5 times higher, and K, which was 139.5 and 3.2 times higher in the aboveground biomass of Quesnelia quesneliana compared to Neoregelia cruenta and Billbergia amoena, respectively (Table 2 ).

This scenario indicated that Neoregelia cruenta presented high concentrations of $\mathrm{N}$ and $\mathrm{P}$, and intermediate of K. In Billbergia amoena occurred high concentrations of $\mathrm{N}$, intermediate concentrations of $\mathrm{P}$ and lower concentrations of $\mathrm{K}$. In Quesnelia quesneliana were observed lower concentrations of $\mathrm{N}$ and $\mathrm{P}$, but also the highest concentrations of K. Nevertheless, the decreasing order of species in terms of nutrient contents was: Quesnelia quesneliana > Neoregelia cruenta > Billbergia amoena. This same order was verified for the aboveground biomass. Therefore, the content of nutrients stored in bromeliads was mainly influenced by the amount of biomass, and not by the concentration of nutrients.

Epiphytic bromeliads obtain nutrition resources by intercepting through fall and stem flow in forests (Lang et al., 1976). The rosettes funnel-shaped form of bromeliads "tank" that store rain water and also intercept nutrients from the atmosphere and from litter fall of others plants and animals associated with bromeliads, allow the accumulation of nutrients that are directly available for them (Larcher, 2000). It is probably that the litter fall from trees trapped inside the tank of terrestrial bromeliads is decomposed more rapidly than in the soil of the dune forest at Restinga da Marambaia, due to the greater quantity and diversity of microbial decomposers within this structure (MG Pereira, unpublished data). This fact directly contributes to greater availability of nutrients to terrestrial bromeliads from the area of the present work.

These uptake mechanisms of nutritional resources may explain the high concentration of nutrients in bromeliads aboveground biomass, despite their reduced biomass (Hsu et al., 2002). Thus, these plants increment the pool of nutrients in forest ecosystems (Oliveira, 2004).

The importance of the epiphytic plants in Tropical Forests nutrient cycling, including bromeliads, has been studied in a few forest ecosystems. Although the biomass of epiphytic plants have corresponded to only $2 \%$ of the total aboveground biomass, the contents of $\mathrm{N}, \mathrm{P}, \mathrm{K}, \mathrm{Ca}$ and $\mathrm{Mg}$ was high and ranged from $21 \%$ to $43 \%$ of the total content of nutrients in the total leaf biomass due to their high concentrations in the leaves, and their biomass have corresponded to $43 \%$ of the total leaf biomass in a Tropical Rain Forest in Taiwan (Hsu et al. 2002).

Similar results were observed in a Tropical Rain Forest in Costa Rica, where the biomass of epiphytes accounted for only $0.5 \%$ of the total aboveground biomass but, because the biomass of epiphytes have been equivalent to $30 \%$ of the total leaf biomass, compared to this, the first stored up to $45 \%$ of total contents of $\mathrm{N}, \mathrm{P}, \mathrm{K}, \mathrm{Ca}$ and $\mathrm{Mg}$ in total leaf biomass of the forest (Nadkarni, 1984). Litter of epiphytic bromeliads presented higher concentration of N, P, K, $\mathrm{Ca}$ and $\mathrm{Mg}$ than the total litter fall at Parque Estadual da Ilha Grande, State of Rio de Janeiro (Oliveira, 2004).

Thus, epiphytic bromeliads contributed with approximately $5.4 \%, 4.8 \%$ and $18.7 \%$ input of $\mathrm{N}, \mathrm{P}$ and $\mathrm{K}$, respectively, via total litter fall, despite its relatively low litter production, only about 3.1\% of total litter fall in Atlantic Forest (Oliveira, 2004). However, the importance of epiphytes in nutrient cycling is practically restricted to primary forests, where their biomass is between 40 and 100 times higher than in secondary forests, as demonstrated in Tropical Forests in Costa Rica (Nadkarni et al., 2004).

The role of terrestrial bromeliads in nutrient cycling may be compared to epiphytic bromeliads, according to numerous ecophysiological similarities between these groups, as attested by an extensive review (Martin, 1994). The mineralization of N, P, Ca and Mg from bromeliads litter was slower than that observed for the trees litter fall, despite the relative higher nutrient concentrations in bromeliads biomass than in that of trees, in a Tropical Rain Forest in Costa Rica (Nadkarni \& Matelson, 1992). This fact is due to the decreased activity of decomposing fungi in soil caused by the organic matter from bromeliads, according to results obtained for the terrestrial Bromelia pinguin L. in Lowland Tropical Forests in Costa Rica (Looby \& Eaton, 2014).

Several mechanisms are particularly well developed in tropical forest ecosystems in oligotrophic sites for capturing and retaining nutrients in the system 
(Herrera et al., 1978; Jordan, 1991). In plant communities that colonize sandy low fertility substrate in dunes, most part of absorbing roots (> 75\%) are concentrated in the upper soil layers and the mineralization of organic matter occurs slowly, revealing nutrient conservative mechanisms in these ecosystems (Conn \& Day, 1993). The slow mineralization of litter causes slow pulses of nutrient in the soil so that these elements may be promptly obtained by other plant species, reducing losses in the ecosystem.

This role may be attributed to bromeliads in the forest dune at Restinga da Marambaia, where field observations indicated the widely presence of fine roots of trees and shrubs near the soil surface, involving the bases of bromeliads. In this ecosystem, it was found higher concentrations of $\mathrm{P}, \mathrm{K}, \mathrm{Ca}$ and $\mathrm{Mg}$ in topsoil under Neoregelia cruenta than in the soil in an adjacent area with bare soil (Pereira et al., 2005). Therefore, the important presence of terrestrial bromeliads in the herbaceous layer of the forest in the study area suggests that these plants have an efficient nutrient cycling. For this reason, bromeliads act as "catalysts" organisms of nutrient dynamics in these vegetation types. Thus, the study of the bromeliads contribution in nutrient cycling presents a new investigative axis for understanding the maintenance of forest systems in Restingas.

\section{CONCLUSIONS}

1) Almost all of the bromeliad aboveground biomass was composed of leaves. Quesnelia quesneliana presented the highest biomass due to higher number of green and dead leaves, and the lowest biomass occurred in Billbergia amoena due to lower mean values for all allometric variables.

2) Diameter and height were the variables that best correlated with the aboveground biomass in $Q$. quesneliana and total number of leaves was the variable that best correlated with the aboveground biomass in B. amoena and Neoregelia cruenta.

3) In general, the concentration of nutrients in aboveground biomass of bromeliads followed the descending order: $\mathrm{K}>\mathrm{N}>\mathrm{P}$. The highest concentrations of $\mathrm{N}$ and $\mathrm{P}$ were observed in
N. cruenta, and K in Q. quesneliana. The lowest concentrations of $\mathrm{N}$ and $\mathrm{P}$ occurred in Q. quesneliana, and $\mathrm{K}$ in B. amoena.

4) Nutrient contents were determined mainly by the amount of aboveground biomass. The greatest potential for nutrient storage occurred in Q. quesneliana and the lowest in B. amoena.

\section{ACKNOWLEDGEMENTS}

To Fundação Boticário.

\section{SUBMISSION STATUS}

Received: 27 july, 2014

Accepted: 15 dec., 2015

\section{CORRESPONDENCE TO}

\section{Marcos Gervasio Pereira}

Departamento de Solos, Universidade Federal Rural do Rio de Janeiro - UFRRJ, Rodovia BR $465 \mathrm{Km}$ 7, CEP 23897-900, Seropédica, RJ, Brasil e-mail: gervasio@ufrrj.br

\section{REFERENCES}

Albuquerque SG, Bandeira GRL. Effect of thinning and slashing on forage phytomass from a caatinga of Petrolina, Pernambuco, Brazil. Pesquisa Agropecuária Brasileira 1995; 30: 885-891.

Alves LF, Vieira SA, Scaranello MA, Camargo PB, Santos FAM, Joly CA et al. Forest structure and live aboveground biomass variation along an elevational gradient of tropical Atlantic moist forest (Brazil). Forest Ecology and Management 2010; 260(5): 679-691. http://dx.doi. org/10.1016/j.foreco.2010.05.023.

Araujo DSD, Scarano FR, Sá SFC, Kurtz BC, Zaluar HLT, Montezuma RCM et al. Comunidades vegetais do Parque Nacional da Restinga de Jurubatiba. In: Esteves FA, editor. Ecologia das lagoas costeiras do Parque Nacional da Restinga de Jurubatiba e do Município de Macaé (RJ). Rio de Janeiro: NUPEM-UFRJ; 1998. p. 39-62.

Araújo TM, Higuchi N, Carvalho-Júnior JA. Comparison of formulae for biomass content determination in a tropical rain forest site in the state of Pará, Brazil. Forest Ecology and Management 1999; 117(1-3): 43-52. http://dx.doi. org/10.1016/S0378-1127(98)00470-8.

Assis MA, Prata EMB, Pedroni F, Sanchez M, Eisenlohr PV, Martins FR et al. Restinga and lowland forests in coastal 
plain of southeastern Brazil: vegetation and environmental heterogeneity. Biota Neotropica 2011; 11(2): 103-121. http://dx.doi.org/10.1590/S1676-06032011000200012.

Burger DM, Delitti WBC. Allometric models for estimating the phytomass of a secondary Atlantic Forest area of southestern Brazil. Biota Neotropica 2008; 8(4): 131-136. http://dx.doi.org/10.1590/S1676-06032008000400012.

Carvalho ALG, Araujo AFB. Ecomorphometric structure of Restinga da Marambaia lizard community, Rio de Janeiro, southeastern Brazil. Revista Brasileira de Zoologia 2007; 24(3): 786-792. http://dx.doi.org/10.1590/S010181752007000300030 .

Cogliatti-Carvalho L, Freitas AFN, Rocha CFD, van Sluys M. Variação na estrutura e na composição de Bromeliaceae em cinco zonas de restinga no Parque Nacional da Restinga de Jurubatiba, Macaé, RJ. Brazilian Journal of Botany 2001; 24(1): 1-9. http://dx.doi.org/10.1590/S010084042001000100001 .

Conn CE, Day FP. Belowground biomass patterns on a coastal barrier island in Virginia. Bulletin of the Torrey Botanical Club 1993; 120(2): 121-127. http://dx.doi. org/10.2307/2996941.

Correia CMB, Dias ATC, Scarano FR. Plant-plant associations and population structure of four woody plant species in a patchy coastal vegetation of Southeastern Brazil. Brazilian Journal of Botany 2010; 33(4): 607-613.

Delitti WBC. Estudos de ciclagem de nutrientes: instrumentos para a análise funcional de ecossistemas terrestres. In: Esteves FA, editor. Oecologia Brasiliensis: estrutura, funcionamento e manejo de ecossistemas brasileiros. Rio de Janeiro: IB/UFRJ; 1995. p. 469-486. vol. 1.

Dias ATC, Mattos EA, Vieira AS, Azeredo JV, Scarano FR. Aboveground biomass stock of native woodland on a Brazilian sandy coastal plain: estimates based on the dominant tree species. Forest Ecology and Management 2006; 226(1-3): 364-367. http://dx.doi.org/10.1016/j. foreco.2006.01.020.

Favretto MA, Hoeltgebaum MP, Lingnau R, D’Agostini FM. Entomofauna em duas espécies de bromélias no oeste de Santa Catarina, Brasil. EntomoBrasilis 2011; 4(1): 10-12. http://dx.doi.org/10.12741/ebrasilis.v4i1.126.

Freitas AFN, Cogliatti-Carvalho L, Sluys MV, Rocha CFD. Distribuição espacial de bromélias na restinga de Jurubatiba, Macaé, RJ. Acta Botanica Brasílica 2000; 14(1): 175-180.

Golley FB, McGinnis JT, Clements RG, Child GI, Duever MJ. Ciclagem de minerais em um ecossistema de floresta tropical úmida. São Paulo: EPU/EDUSP, 1978. 256 p.

González AL, Fariña JM, Pinto R, Pérez C, Weathers KC, Armesto JJ et al. Bromeliad growth and stoichiometry: responses to atmospheric nutrient supply in fog-dependent ecosystems of the hyper-arid Atacama Desert, Chile.
Oecologia 2011; 167(3): 835-845. http://dx.doi.org/10.1007/ s00442-011-2032-y. PMid:21660582.

Hay JD, Henriques RPB, Costa SRA. Uma avaliação preliminar da possibilidade de usar equações de regressão para estimativas da biomassa na restinga. Revista Brasileira de Botânica 1982; 5: 33-36.

Hay JD, Lacerda LD. Ciclagem de nutrientes do ecossistema de Restinga. In: Lacerda LD, Araujo DSD, Turcq B, editors. Restingas: origens, estrutura, processos. Niterói: CEUFF; 1984. p. 459-475.

Henriques RPB, Araujo DSD, Hay JD. Descrição e classificação dos tipos de vegetação da restinga de Carapebus, Rio de Janeiro. Revista Brasileira de Botânica 1986; 9: 173-189.

Herrera RCF, Klinge H, Medina E. Amazon ecosystems: their structure and functioning with particular emphasis on nutrients. Interciência 1978; 3(4): 223-232.

Hofstede RGM, Wolf JHD, Benzing DH. Epiphyte biomass and nutrient status of a Colombian upper montane rain forest. Selbyana 1993; 14: 37-45.

Hsu CC, Horng FW, Kuo CM. Epiphyte biomass and nutrient capital of a moist subtropical forest in northeastern Taiwan. Journal of Tropical Ecology 2002; 18(05): 659-670. http://dx.doi.org/10.1017/S0266467402002432.

Jordan CF. Nutrient cycling processes and tropical forest management. In: Gomes-Pompa A, Whitmore, TC, Hadley $\mathrm{M}$, editors. Rain forest regeneration and management. Paris: Unesco; 1991.p. 159-180. Man and the Biosfere Series n. 6.

Köppen W. Climatologia: con un estudio de los climas de la tierra. México: Fondo de Cultura Econômica; 1948. 479 p.

Lang GE, Reiners WA, Heier RK. Potential alteration of precipitation chemistry by epiphytic lichens. Oecologia 1976; 25(3): 229-241. http://dx.doi.org/10.1007/BF00345100.

Larcher W. Ecofisiologia vegetal. São Carlos: RiMa Artes e Textos; 2000.531 p.

Looby C, Eaton WD. Effects of Bromelia pinguin (Bromeliaceae) on soil ecosystem function and fungal diversity in the lowland forests of Costa Rica. BMC Ecology 2014; 14(1): 12-19. http://dx.doi.org/10.1186/1472-678514-12. PMid:24885984.

Martin CE. Physiological ecology of the Bromeliaceae. Botanical Review 1994; 60(1): 1-82. http://dx.doi. org/10.1007/BF02856593.

Mattos CLV. Caracterização climática da Restinga da Marambaia. In: Menezes LFT, Peixoto AL, Araujo DSD, editors. História natural da Marambaia. Seropédica: EDUR; 2005. p. 55-66.

Menezes LFT, Araujo DSD. Formações vegetais da Restinga da Marambaia. In: Menezes LFT, Peixoto AL, Araujo DSD, editors. História natural da Marambaia. Seropédica: EDUR; 2005. p. 67-120.

Menezes LFT, Araujo DSD. Variação da biomassa aérea de Allagoptera arenaria (Gomes) O. Kuntze numa comunidade 
arbustiva de Palmae na Restinga da Marambaia-RJ. Brazilian Journal of Biology $=$ Revista Brasileira de Biologia 2000; 60(1): 147-157. http://dx.doi.org/10.1590/S003471082000000100017. PMid:10838933.

Menezes LT, Peixoto AL, Araujo DSD. História natural da Marambaia. Seropédica: EDUR; 2005. 288 p.

Moraes RM, Delitti WBC, Vuono YS. Litterfall and litter nutrient content in two Brazilian Tropical Forests. Revista Brasileira de Botânica 1999; 22(1): 9-16.

Moreira-Burger D, Delitti WB. Modelos preditores da fitomassa aérea da Floresta Baixa de Restinga. Revista Brasileira de Botânica 2010; 33(1): 143-153. http://dx.doi. org/10.1590/S0100-84042010000100013.

Moreira-Burger D, Delitti WBC. Fitomassa epigéa da mata ciliar do Rio Mogi-Guaçu, Itapira - SP. Revista Brasileira de Botânica 1999; 22(3): 429-435. http://dx.doi. org/10.1590/S0100-84041999000300011.

Nadkarni NM, Matelson TJ. Biomass and nutrient dynamics of epiphytic litter fall in a Neotropical montane forest, Costa Rica. Biotropica 1992; 24(1): 24-30. http://dx.doi. org/10.2307/2388470.

Nadkarni NM, Schaefer D, Matelson TJ, Solano R. Biomass and nutrient pools of canopy and terrestrial componentes in a primary and a secondary montane cloud forest, Costa Rica. Forest Ecology and Management 2004; 198(1-3): 223-236. http://dx.doi.org/10.1016/j.foreco.2004.04.011.

Nadkarni NM. Epiphyte biomass and nutrient capital of a neotropical elfin forest. Biotropica 1984; 16(4): 249-256. http://dx.doi.org/10.2307/2387932.

Oliveira RR. Importância das bromélias epífitas na ciclagem de nutrientes da Floresta Atlântica. Acta Botanica Brasílica 2004; 18(4): 793-799. http://dx.doi.org/10.1590/ S0102-33062004000400009.

Paula RR, Pereira MG, Menezes LFT. Aporte de nutrientes e decomposição da serapilheira em três fragmentos florestais periodicamente inundados na Ilha da Marambaia, RJ. Ciência Florestal 2009; 19(2): 139-148. http://dx.doi. org/10.5902/19805098405.

Pereira MG, Menezes LFT, Silveira Filho TB, Silva AN. Propriedades químicas de solos sob Neoregelia cruenta (R. Grah) L. B. Smith na restinga da Marambaia, RJ. Floresta e Ambiente 2005; 12(1): 70-73.

Pereira MG, Silva NA, Paula RR, Menezes LFT. Aporte e decomposição de serapilheira em floresta periodicamente inundável na Restinga da Marambaia, RJ. Ciência Florestal 2012; 22(1): 59-67. http://dx.doi.org/10.5902/198050985079.

Pires LA, Britez RM, Martel G, Pagano SN. Produção, acúmulo e decomposição da serapilheira em uma restinga da Ilha do Mel, Paranaguá, PR, Brasil. Acta Botanica Brasílica 2006; 20(1): 173-184. http://dx.doi.org/10.1590/ S0102-33062006000100016.

Roncarati H, Menezes LFT. Marambaia, Rio de Janeiro: origem e evolução. In: Menezes LFT, Peixoto AL, Araujo DSD, editors. História natural da Marambaia. Seropédica: Editora da Universidade Federal Rural do Rio de Janeiro; 2005. p. 15-38.

Scarano FR. Plant communities at the periphery of the Atlantic rain forest: rare-species bias and its risks for conservation. Biological Conservation 2009; 142(6): 1201 1208. http://dx.doi.org/10.1016/j.biocon.2009.02.027.

Tedesco MJ, Gianello C, Bissani CA, Bohnen H, Volkweiss SJ. Análise de solo, plantas e outros materiais. 2nd ed. Porto Alegre: UFRGS; 1995. 174 p.

Teixeira RL, Schineider JAP, Almeida GI. The occurrence of amphibians in bromeliads from a southeastern brazilian restinga habitat, with special reference to Aparasphenodon brunoi (Anura, Hylidae). Brazilian Journal of Biology = Revista Brasileira de Biologia 2002; 62(2): 263-268. http://dx.doi.org/10.1590/S1519-69842002000200010. PMid:12489399.

Tiepolo G, Calmon M, Feretti AR. Measuring and monitoring carbono stocks at the Guaraquec, aba Climate Action Projetct, Paraná, Brasil. In: Proceedings of the International Symposium on Forest Carbon Sequestration and Monitoring [online]; 2002; Taipei, Taiwan. Taipei: Taiwan Forestry Research Institute; 2002. p. 98-115. Extension Series. [cited 2014 July 27]. Available from: http://www.spvs. org.br/download/monitoramento ingles.pdf

van Sluys M, Rocha CFD, Hatano FH, Boquimpani-Freitas L, Marra LV. Anfíbios da restinga de Jurubatiba: composição e história natural. In: Rocha CFD, Esteves FA, Scarano FR, editors. Pesquisas de longa duração na restinga de Jurubatiba. Ecologia, história natural e conservação. São Carlos: RiMa; 2004. p. 165-178.

Vieira AS, Alves LF, Aidar MPM, Araujo LS, Baker T, Batista JLF et al. Estimation of biomass and carbon stocks: the case of the Atlantic Forest. Biota Neotropica 2008; 8(2): 21-29. http://dx.doi.org/10.1590/S1676-06032008000200001. 